\title{
Investigations of the capacity and strength of seed germination in Allium victorialis L.
}

\author{
Krystyna Winiarczyk ${ }^{1 *}$, Katarzyna Skrzypczak², Jolanta Jaroszuk-Ściseł ${ }^{3}$, Jan Bocianowski ${ }^{4}$ \\ ${ }^{1}$ Department of Plant Anatomy and Cytology, Maria Curie-Skłodowska University, Akademicka 19, 20-033 Lublin, Poland \\ ${ }^{2}$ Faculty of Food Science and Biotechnology, University of Life Sciences in Lublin, Skromna 8, 20-704 Lublin, Poland \\ ${ }^{3}$ Department of Environmental Microbiology, Maria Curie-Skłodowska University, Akademicka 19, 20-033 Lublin, Poland \\ ${ }^{4}$ Department of Mathematical and Statistical Methods, Poznań University of Life Sciences, Wojska Polskiego 28, 60-637 Poznań, Poland
}

\begin{abstract}
The aim of the study was to examine the strength and energy of seed germination in Allium victorialis. Despite the normal structure of seeds containing a viable embryo and compliance with all International Seed Testing Association recommendations, no germination in A. victorialis was observed. Additionally, the scarification and stratification treatments applied did not improve the dynamics of germination of $A$. victorialis seeds. Microbiological analyses of soil sampled from natural localities of the plant revealed a typical composition of bacteria and fungi. The high number of fungi $\left[4.5 \log _{10} \mathrm{CFU}\right.$ (colony forming units) of fungi $\times \mathrm{g}^{-1}$ dry mass of soil] and various groups of bacteria (about $7.0 \log _{10} \mathrm{CFU}$ of bacteria $\times \mathrm{g}^{-1}$ dry mass of soil) were detected in the root-free-soil around garlic roots. In the interior of $A$. victorialis roots, the number of microorganisms decreased 1000 to 10000 times but all the tested microbial groups, especially copiotrophic bacteria and fungi (1.6 and 2.2, respectively, $\log _{10} \mathrm{CFU} \times \mathrm{g}^{-1}$ dry mass of roots) were detected.

Changes in such parameters as dehydrogenase activity, $\mathrm{pH}$ values, and the total organic $\mathrm{C}$ (TOC) content in the particular parts of the rhizosphere and in comparison to the rhizosphere with root-free-soil were observed. The dehydrogenase activity and TOC content were highly positively correlated with the total number of CFU of the microorganisms.
\end{abstract}

Keywords: Allium; victory onion; phylogenetic analysis; ISTA; seed; embryo; tetrazolium test

\section{Introduction}

Although ontogenetic development of plants begins with zygote formation, it is assumed that seed germination is the actual first stage of development, during which a new individual starts its independent existence, often at a long distance from the parental plant. Therefore, seeds are both the end of the plant developmental cycle and the beginning.

In Angiospermae, after double fertilization, the embryo matures and becomes a seed enclosed within the fruit. The seed contains an embryo, endosperm, and a seed coat. The embryo represents a miniature plant with vegetative organ buds: the root, stem, and leaves [1]. In Mononocots, seed coats are not distinct structures being fused with the fruit wall to form a pericarp. The seed coat forms from the two integuments or outer layers of cells of the ovule, which derive from tissue from the mother plant, the inner integument forms the tegmen and the outer forms the testa. The seed is cover with the testa, which has a protective role against

\footnotetext{
* Corresponding author. Email: krystyna.winiarczyk@poczta.umcs.lublin.pl
} Handling Editor: Elżbieta Bednarska-Kozakiewicz infections, pests, and adverse external conditions. It is usually hard and formed the mechanical layer. The cells of the seed testa become hard due to deposition of cutin, lignin, and phenolic compounds in the cell walls. The developing embryo acquires nutrients from the endosperm. This nutritive tissue is usually triploid and begins to develop immediately after fertilization through merging of the central cell in the embryo sac with the sperm nucleus. The primary endosperm nucleus usually undergoes mitotic divisions before zygote divisions. The endosperm is rich in carbohydrates, proteins, and fats; hence, the division into starch (cereals), oil (rapeseed, sunflower), and protein seeds (legume plants). Moreover, the endosperm contains hormones responsible for embryo development $[2,3]$.

Seed germination is a set of processes leading to activation of embryos followed by initiation of seedling growth. Germination conditions are strictly defined and specific for individual species. The onset and course of the seed germination process depends on many environmental factors, e.g. minimum, maximum, and optimal temperature. Seed germination in a majority of plants is dependent on light conditions; such seeds are named photoblastic and they represent positive (light-stimulated germination) and 
negative photoblasty (light-inhibited germination). However, light availability does not determine the process. A majority of positively photoblastic seeds germinate in darkness as well, yet light conditions have a favorable effect on germination efficiency [4]. Other environmental conditions regulating the course of seed germination include substances present in the atmosphere and the substrate and water availability. Presence of oxygen is essential for normal germination in all seeds, as lack thereof results in a slower germination rate and the developing seedlings exhibit developmental anomalies. In general, seeds are well equipped with mineral compounds by the parent plant; therefore, the content of these compounds in the substrate has no significant effect on the germination process. Nitrates, however, available in the substrate exert a significant impact on germination. As a rule, their presence enhances (sometimes several fold) the germination efficiency, which is probably a result of the oxidative activity of $\mathrm{NO}^{3-}$ ions. Given the nature of processes predominant in the germination process, three basic stages can be distinguished, i.e. imbibition, catabolic, and anabolic phases. The kinetics of water and oxygen uptake by germinating seeds is a factor that differentiates the individual germination phases [5]. For seed germination, some plant species require specific treatment such as scarification and stratification. Overcoming seed dormancy may involve mechanical damage to or removal of the seed coat or application of low temperature (vernalization). Additionally, each plant species needs a different duration of dormancy. Some seeds germinated immediately after harvest, while others require some dormancy period. Laboratory qualification of the seed material must be based on the recommendations included in the "International rules for seed testing" (by International Seed Testing Association - ISTA), which contain rules of the methodology of sampling and testing the sowing value of various characteristics of seeds from over 900 plant species.

Allium victorialis L. occurs on and mountain pasture and meadows, stony slopes and rocky sites. The wide geographical range of the species covers Europe, Asia, and North America [6]. In Asia, the species grows in the area between the Ural Mountains and Kamchatka [7]. It is a typical representative of alpine flora. In Asia and the Caucasus, it occurs at an altitude of 1700-2600 m a.s.l. In Central Europe, A. victorialis is a rare plant threatened with extinction. The species has been included in the red list of plants and fungi in Poland and regarded as endangered [8]. In the European red list of vascular plants (2002), the species has been classified as LC, i.e. least concern. In the neighboring countries, e.g. in Germany, the species occurs only in Baden-Württemberg, where it has been classified as threatened (category $1 \mathrm{CR}$ - critically endangered according to the IUCN categories). In the Czech Republic, it was assigned to category C2, which corresponds to EN in the IUCN category and in Slovakia the species is included in the red list [9]. A. victorialis is a typical entomophilous species pollinated by Diptera and Hymenoptera insects. The number of pollen grains produced by the male flower reaches 4.8-6.0 $\times 104$, whereas the amount of pollen produced by one plant ranges from $1.22 \times 106$ to $2.12 \times 106$. The species reproduces sexually through seeds and employs vegetative reproduction by separation of a part of the roots from the parent plant [10]. A. victorialis leaves are edible and the plant is a source of valuable bioactive substances used in pharmacy and gastronomy. In the past, the species was known as the so-called false mandrake, and its root successfully replaced the real Mandragora officinarum [11].

The aim of the study was to examine the strength and energy of $A$. victorialis germination proceeding in accordance with the ISTA guidelines and to perform a preliminary analysis of the causes of inhibited seed germination. The study also provides determination of relatedness and phylogenetic relationships between Allium species. Additionally, soil microflora as well as dehydrogenase activity, which catalyzes oxyreductive reactions occurring in every living cell, has been examined [12].

\section{Material and methods}

\section{Plant material}

The examined plants originated from the collections of the Maria Curie-Skłodowska University Botanical Garden in Lublin. Three Allium species were investigated:

(i) Allium victorialis L. - a critically endangered species included in the red list of plants and fungi in Poland (2006) and regarded as endangered in Poland; it was introduced from a natural locality in the Bieszczady Mountains in 1968.

(ii) Allium angulosum L. - a species included in the red list of plants and fungi in Poland (2006) and regarded as vulnerable in Poland ( $\mathrm{V}$ category). The species was introduced in the UMCS Botanical Garden from Germany in 1974.

(iii) Allium tuberosum Roxb. - a species naturally occurring in Asia; in Europe, it is cultivated as both an ornamental and a usable plant; it was introduced from the Gatersleben Botanical Garden, Seeland, Germany in 1996. Its natural locality is Nepal.

\section{Growth conditions}

Breeding experiment was conducted in Poland in the Lublin $\left(51^{\circ} 16^{\prime} \mathrm{N}, 22^{\circ} 30^{\prime} \mathrm{E}\right), 200 \mathrm{~m}$ a.s.l. The climate of a region is characterized by prevalence of continental features with high annual temperature amplitudes, long summers and long and cold winters. In the years 1951-2012 long-term mean annual temperature reached $8.3^{\circ} \mathrm{C}$, and long-term mean annual precipitation sum achieved $550.6 \mathrm{~mm}$.

Terrain relief can be described as a western slope dissected by three loess ravines with a loess podzolic soils.

\section{Phylogenetic analyses}

Genetic material was extracted from young leaves. A fragment of the internal transcribed spacer (ITS) region was amplified using primers ITS4 and ITS5. Freshly harvested young leaves of Allium victorialis, A. angulosum and A. tuberosum were collected from six randomly selected plants placed in Eppendorf tubes and stored at $-80^{\circ} \mathrm{C}$. Total DNA was extracted from leaf tissue using an Isolate Plant Mini Kit for DNA isolation according to the procedure recommended by the producer company BIOLINE. For molecular characterization and phylogenetic analyses, the regions of the nuclear ribosomal DNA gene cluster were 
amplified using ITS4 and ITS5 primers (Tab. 1) [13]. PCR was carried out in a $20 \mu \mathrm{l}$ reaction mixture containing: $1 \mu \mathrm{l}$ of each primer $(20 \mathrm{pmol} / \mu \mathrm{l}$; Genomed), $7 \mu \mathrm{l}$ free RNAse water (Fermentas), $10 \mu \mathrm{l} \mathrm{MyTaq}{ }^{\text {TM }}$ RedMix ready-to-use $2 \times$ $(0.05 \mathrm{u} / \mu \mathrm{l}$ Taq polymerase; reaction buffer, $4 \mathrm{mM} \mathrm{MgCl}$; $0.4 \mathrm{mM}$ each of dNTP: dATP, dCTP, dGTP, dTTP; loading color buffer) and $1 \mu \mathrm{l}$ DNA (100 ng/ $\mu \mathrm{l})$.

Tab. 1 Specifications of the primers.

\begin{tabular}{llccc}
\hline Name & Sequence & $\boldsymbol{T}\left({ }^{\circ} \mathbf{C}\right)$ & Length & \%GC \\
\hline ITS5 & $\begin{array}{l}\text { 5'-GGAAGTAAAAGTCGTAAC } \\
\text { AAGG-3' }\end{array}$ & 51.1 & $22 \mathrm{nt}$ & 41 \\
& $\begin{array}{l}\text { ITS4 } \\
\text { 5'-TCCTCCGCTTATTGAT } \\
\text { ATGC-3' }\end{array}$ & 49.7 & $20 \mathrm{nt}$ & 45 \\
\end{tabular}

* The percentage of guanine-cytosine pairs.

Amplifications were performed in a PTC-200 thermocycler (MJ-Research, USA) under the following conditions: initial denaturation for $2 \mathrm{~min}$ at $94^{\circ} \mathrm{C}, 30$ cycles of $1 \mathrm{~min}$ at $94^{\circ} \mathrm{C}, 1 \mathrm{~min}$ at $61^{\circ} \mathrm{C}, 2 \mathrm{~min}$ at $72^{\circ} \mathrm{C}$, followed by $7 \mathrm{~min}$ at $72^{\circ} \mathrm{C}$. Amplification products were separated on $1.5 \%$ agarose gel (Invitrogen) in TBE (Tris/borate/EDTA) buffer (0.178 M Tris-borate, $0.178 \mathrm{M}$ boric acid, $0.004 \mathrm{M}$ EDTA) and stained with ethidium bromide. Ten $\mu$ of PCR products were supplemented with $2 \mu \mathrm{l}$ of loading buffer ( $0.25 \%$ bromophenol blue, $30 \%$ glycerol), prior to agarosegel electrophoresis at $3 \mathrm{~V} \mathrm{~cm}^{-1}$ for about $2 \mathrm{~h}$. A 100-bp DNA Ladder Plus (Fermentas) was used as a size standard. When developed, the gels were viewed under UV light and photographs were taken (Syngen UV visualizer).

After electrophoresis, extraction of amplification products from agarose gel was performed using an Isolate Gel and PCR Kit according to the procedure recommended by the producer company BIOLINE. After extraction and purification from the gel, the amplification products were prepared for sequencing according to the recommendations of Genomed. Uploaded by Genomed sequencing results were analysed in the Finch TV. All nucleotide sequences were transformed in the appropriate format-FASTA, and then read using ClustalW2.

\section{Assessment of the strength and energy of seed germination}

Determination of the germinating capacity of the seeds from the plant material analyzed was performed in accordance with the recommendations included in "International rules for seed testing" [14]. The method provides reproducible results within the limits set by the random variation in the sample. The conditions of the experiments were standardized following the ISTA guidelines to allow control and regulation.

Estimation of the seed germination capacity in each species was performed in 15 replicates using 12 seeds in a Petri dish. Calculations were based on counted numbers of germinating seeds on experimental days $7,10,14$, and 21 .
The germination energy was estimated for the cumulative number of seeds germinating on day 10 . The germination strength was estimated for the cumulative number of seeds germinating on experimental day 21 .

\section{Tetrazolium test for seed viability and vigor}

The tetrazolium test is widely recognized as an accurate means of estimating seed viability. Tetrazolium test results can be extremely valuable for providing labeling information for immediate shipment of seed lots without waiting for completion of germination tests. It is also a valuable research technique for estimating seed viability and determining reasons for poor germination. The staining patterns reveal the live and dead areas of the embryos thus enabling determination whether seeds have the capacity to produce normal seedlings. This biochemical test can distinguish live from dead tissues of seed embryos on the basis of dehydrogenase enzyme activity (respiration enzymes). Upon seed hydration, the activity of dehydrogenase enzymes increases resulting in release of hydrogen ions, which reduce the colorless tetrazolium salt solution (2,3,5-triphenyltetrazolium chloride) into a chemical red compound called formazan. Formazan stains living cells with a red color, while dead cells remain colorless [15].

The analyses were based on the recommendations and methodology contained in the "International rules for seed testing" [14]. The method allows receiving reproducible results, within the limits set by the random variation in the sample. The conditions of the experiment were standardized to allow control and regulation.

Sixty of seeds subjected to the experiment were soaked in sterile distilled water at $20^{\circ} \mathrm{C}$ for 17 hours. They were opened into half and immersed in a $1 \%$ tetrazolium solution ( $\mathrm{pH}$ 6.5). The samples were incubated for 30 minutes at $37^{\circ} \mathrm{C}$. Dried seeds were observed and diagnosed under a microscope.

\section{Scanning electron microscopy (SEM)}

The biological material constituted by 20 seeds of each tested species was fixed in a 5:5:90 (v:v:v) mixture of glacial acetic acid:formalin (40\%):ethanol (70\%) and dehydrated in a graded acetone series (40\%, 70\%, 80\%, 100\%). Subsequently, all material was frozen by using liquid nitrogen. Samples were analyzed in the scanning electron microscope (LEO1430VP) with an accelerating potential of $15 \mathrm{kV}$.

\section{Microbial analysis of root-free-soil, rhizosphere soil and roots}

Cores of soil (brown podzolic soil developed from loess) with $A$. victorialis plants at the full maturity stage of growth were aseptically taken from randomly selected sites in the plots. At the same time, cores of root-free soil (RFS) from the same field (plot) were collected.

Intact cores were placed in plastic bags, returned to the laboratory and stored overnight at $4^{\circ} \mathrm{C}$.

The root contaminated soil (RCS) was obtained through gentle shaking of cores of soil with A. victorialis plants. Next, the plants were carefully removed from the soil and then separated into tops (shoots) and roots.

The roots were gently shaken ( 3 times $-15 \mathrm{~s}$ ) to remove adhering clumps of rhizosphere soil loosely attached to 
roots (RhSL). Next, the garlic roots were placed in sterile glass flasks and shaken for $15 \mathrm{~min}$ at $50 \mathrm{rpm} \mathrm{min}^{-1}$ in an Innova chamber. After this procedure, the roots were separated from the removed rhizosphere soil strongly attached to roots (RhSS) and aseptically transferred to sterile Erlenmayer flasks.

Colonization of the rhizoplane (RhP) was evaluated by the following procedure: samples $(10 \mathrm{~g})$ of roots without RhSS transferred to sterile Erlenmayer flasks with $90 \mathrm{ml}$ of sterile distilled water (SDW) were shaken for $1 \mathrm{~h}$ at $50 \mathrm{rpm}$ $\mathrm{min}^{-1}$ in the Innova chamber. The suspension obtained was used as a source of rhizoplane microorganisms.

Colonization of the RhP and interior of roots was evaluated by the following procedure: samples $(10 \mathrm{~g})$ of roots without RhSS in $90 \mathrm{ml}$ of SDW were homogenized in an Ultra Turrax IKA ${ }^{\oplus}$ T18 homogeniser at $20000 \mathrm{rpm} \mathrm{min}^{-1}$ for $30 \mathrm{~s}$ (the homogenate was cooled in an ice bath). This treatment was repeated three times at 15-s intervals. The homogenate obtained was used as a source of microorganisms colonizing the rhizoplane and interior of the root.

Colonization of the root interior was evaluated by the following procedure: $10 \mathrm{~g}$ samples of roots were surfacedisinfected by brief washing 3 times in SDW for 5 min at

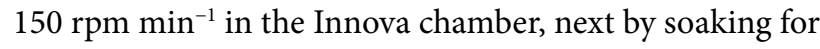
$10 \mathrm{~min}$ in a solution of $\mathrm{HgCl}_{2}(0.1 \%)$, then in $\mathrm{H}_{2} \mathrm{O}_{2}(30 \%)$, and rinsing 10 times in sterile distilled water. Subsequently, the homogenate of the surface-disinfected roots was prepared by the method described above. The homogenate obtained was used as a source of microorganisms colonizing the interior of the root.

Soil colonization - colonization of RFS and RCS as well as rhizosphere soils (RhSL and RhSS) was evaluated by placing $10 \mathrm{~g}$ of soil in a sterile Erlenmayer flasks with $90 \mathrm{ml}$ of SDW followed by shaking for $30 \mathrm{~min}$ at $50 \mathrm{rpm} \mathrm{min}^{-1}$ in the Innova chamber.

The soil dilution technique was used to determine the number of bacterial and fungal colony forming units (CFU) in the soil and roots samples. Seven 10-fold dilutions in $9 \mathrm{ml}$ of SDW were made from the soil and root suspensions obtained and $100 \mu \mathrm{l}$ of each dilution was spread onto the surface of appropriate solid media in Petri dishes.

The number of copiotrophs was determined on plates with PYS $[12,16]$ medium and the number of CFU of oligotrophs was counted on 100 times diluted PYS agar. The numbers of Pseudomonas fluorescens on King's medium B [17] To determine the number of Actinobacteria, RBSCN agar [11] was used. Martin's medium (1950) [18] was used to calculate the total number of fungal CFU.

Colonies of bacterial strains were counted after $48 \mathrm{~h}$ of incubation, and colonies of fungal strains were counted after 7 days of growth at $28^{\circ} \mathrm{C}$. The means of three replicates were expressed as $\log \mathrm{CFU} \times \mathrm{g}^{-1}$ of dry mass (for RFS, RCS, $\mathrm{RhSL}$, RhSS) of soil or dry mass of roots (for RhP and the interior of roots).
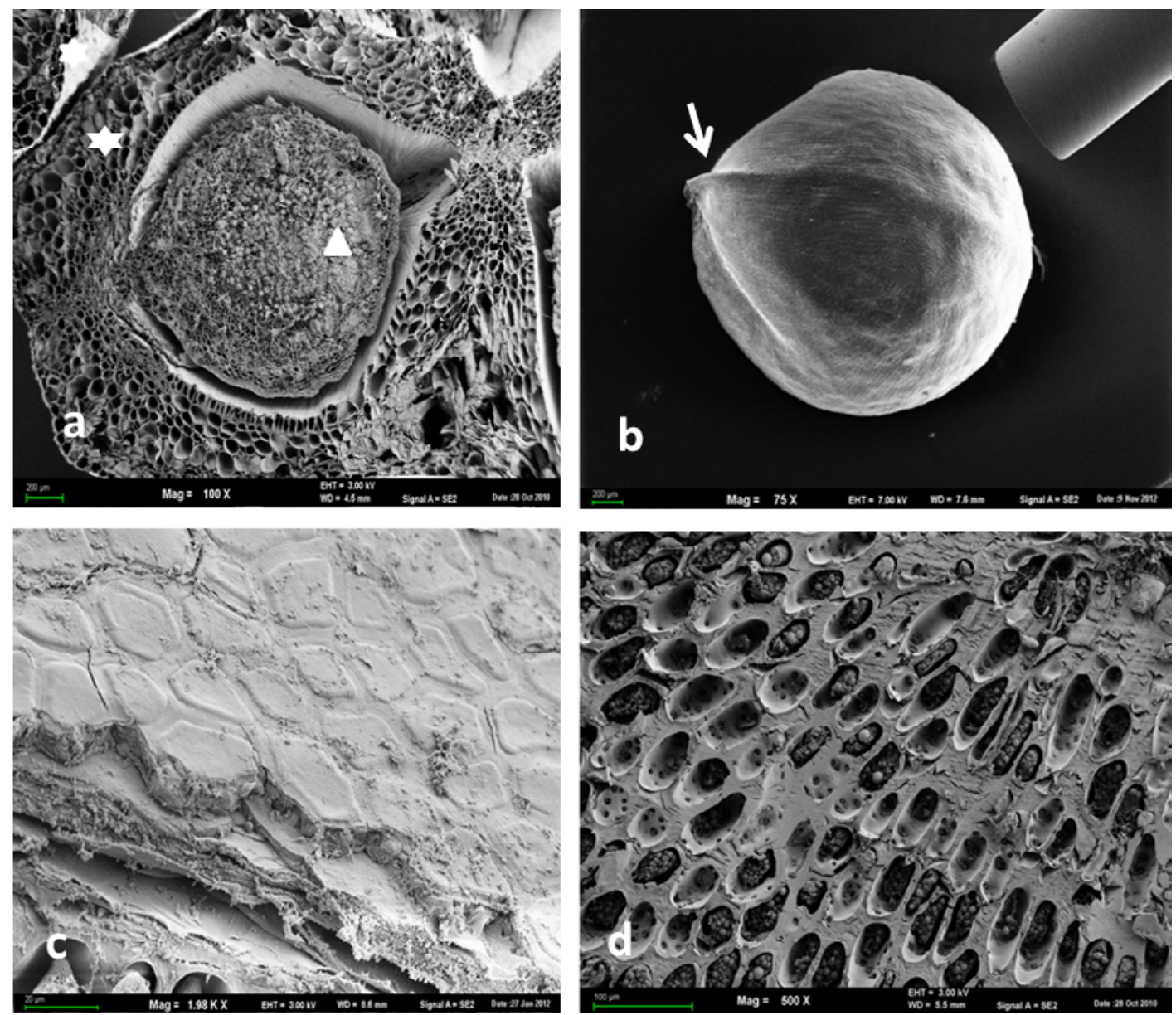

Fig. 1 Allium victorialis. a Ovary cross section with a multilayered pericarp (asterisk); central part taken up by a young seed (arrow). b General view of a victory onion seed; the raphe is marked by an arrow. c Reticulate seed coat surface pattern. $\mathbf{d}$ Seed cross section showing flatted and adhered to each other endosperm cells with starch granules. Scale bars: a,b $200 \mu \mathrm{m} ; \mathbf{c} 20 \mu \mathrm{m} ; \mathbf{d} 100 \mu \mathrm{m}$. 


\section{Dehydrogenase activity}

Dehydrogenase activity was determined using the Tabatabai (1982) [19], Thalmann (1968) [20] method described by Alef [12]; it is based on estimation of the rate of triphenyltetrazolium chloride reduction to triphenyl formazan (TPF) in soils after incubation at $28^{\circ} \mathrm{C}$ for $24 \mathrm{~h}$. TPF was extracted with methanol. The TPF methanol extract was filtered and the optical density of the clear supernatant was measured against the blank at $485 \mathrm{~nm}$ (red color). The total organic carbon content (TOC) was determined using the Tiurin method after vaporizing the sample [16]. The values of $\mathrm{pH}$ were measured with a potentiometer in a $1-\mathrm{mol} \mathrm{dm}^{-3}$ $\mathrm{KCl}$ solution and in water.

\section{Data analysis}

The numbers of microorganisms in root-free-soil, rhizosphere soil, and roots (in three replicates from each treatment) were analyzed for significant differences $(P<0.05)$ by one-way (species) analysis of variance (ANOVA) using Microsoft $^{\oplus}$ Excel 2000 [21]. The CFU of the microorganisms $\times \mathrm{g}^{-1}$ dry mass of soil/root were subjected to analysis of variance (ANOVA), and means were separated using the Neuman-Keuls test at a $5 \%$ level of significance. The coefficients of genetic similarity of the investigated species were calculated. The coefficients were used to group the species hierarchically using the unweighted pair group method of arithmetic means. The phylogenetic similarity among species was presented in the form of a dendrogram. The relationships between observed traits were analyzed by correlation coefficients.

\section{Results}

\section{The structure of the seed in SEM}

A single A. victorialis plant produced 23-35 flowers, which contained between 69 and 105 developing embryos. After fertilization, the trilocular ovary contained a pericarp and a young seed (Fig. 1a). A single plant from the population growing in the natural habitat produced from 14 to 70 seeds, which were black, ovoid, and their size reached approximately $3 \mathrm{~mm}$ (Fig. 1b). The weight of a single seed ranged between 6.0 and $6.7 \mathrm{mg}$. The A. victorialis seed was covered by a thick testa with a raphe visible on its surface. The seed coat was made of strongly flattened cells. The seed coat exhibited irregularly reticulate surface pattern with polygonal epidermal cells (Fig. 1c). The seed interior was filled with the endosperm - a storage tissue containing store substances for the embryo (Fig. 1d). After 21 days, an embryo located peripherally and surrounded by the nutritive tissue developed inside the seed (Fig. 2a). In the early phase of embryonic development, the endosperm contained nutrients
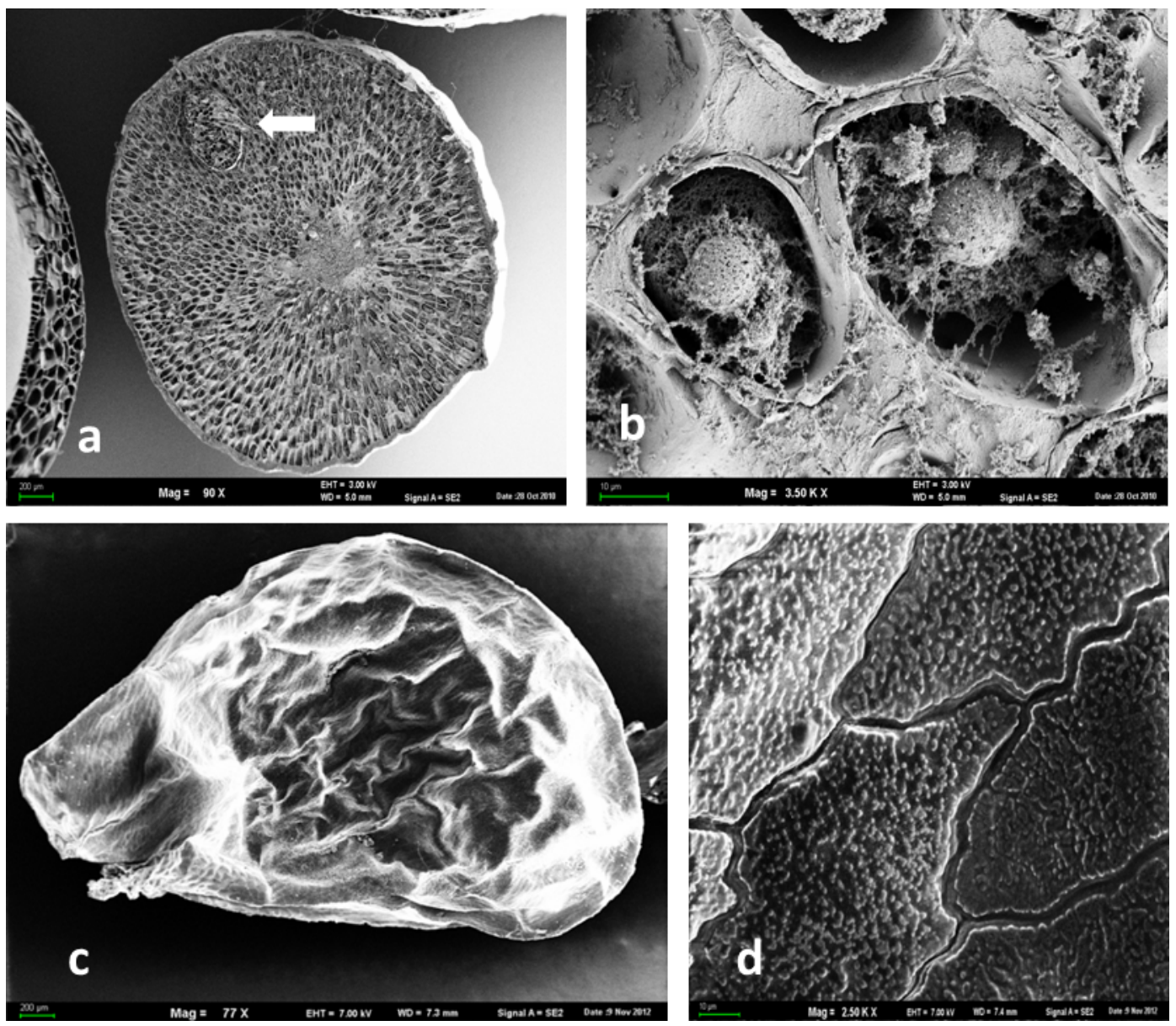

Fig. 2 Allium victorialis after 21 days of the in vitro experiment $(\mathbf{a}, \mathbf{b})$. a The seed cross section with peripheral location of a part of a young seedling (arrow). b Endosperm cells with protoplast remains; the cells have very thick walls; lack of intercellular spaces between them. $\mathbf{c}$ General view of the A. tuberosum seed. $\mathbf{d}$ Reticulate seed coat surface pattern showing irregularly polygonal testa cells of the A. tuberosum seed. Scale bars: a,c $200 \mu \mathrm{m}$; b,d $10 \mu \mathrm{m}$. 

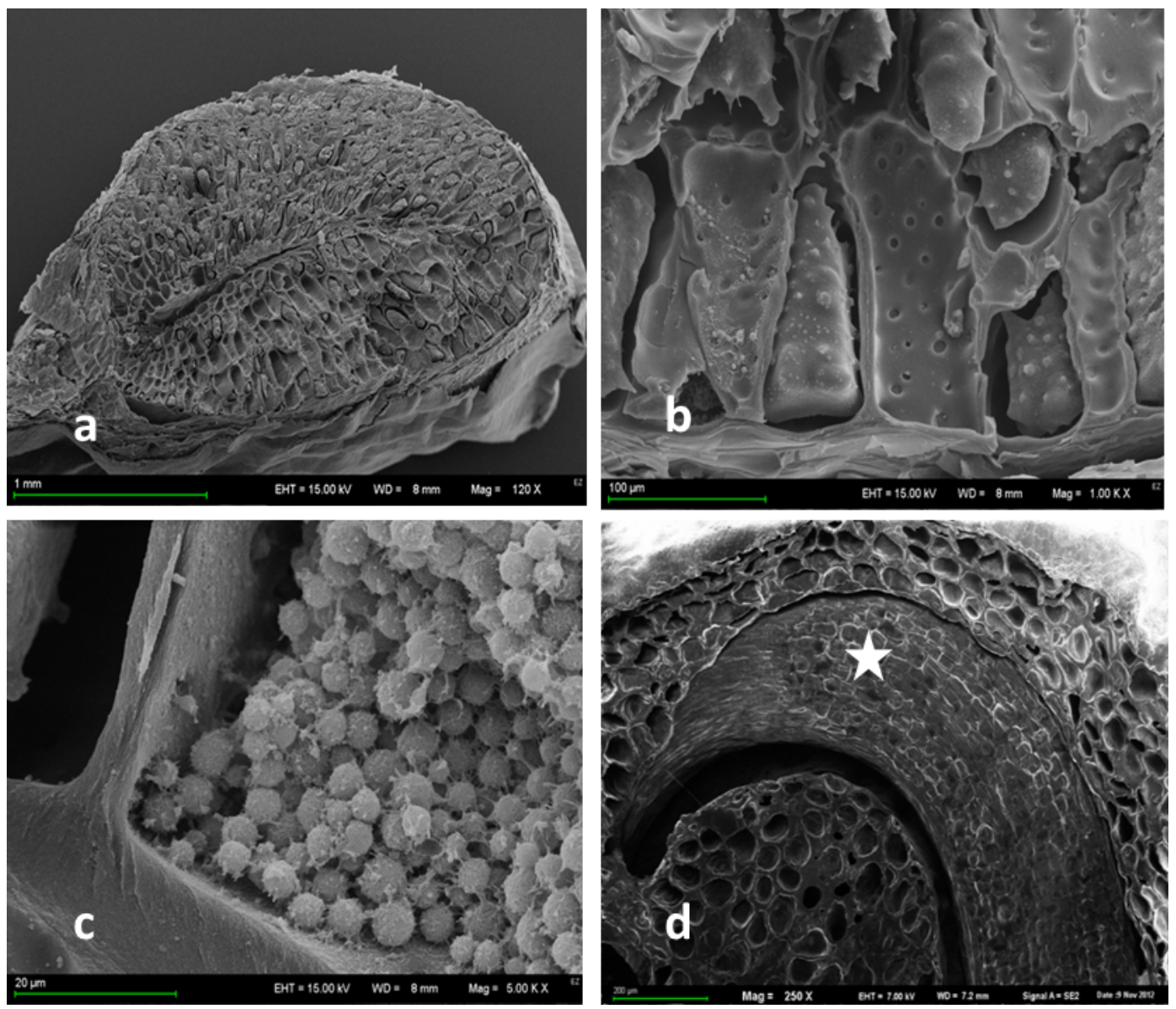

Fig. 3 a Cross section of the Allium angulosum mature seed. $\mathbf{b}$ The aleuronic palisade layer cells in the A. angulosum seed. There are alternately arranged pits in the cell wall. c Starch grains inside the endosperm cell. $\mathbf{d}$ Cross section of a young seedling in the A. angulosum seed (asterisk radicle).
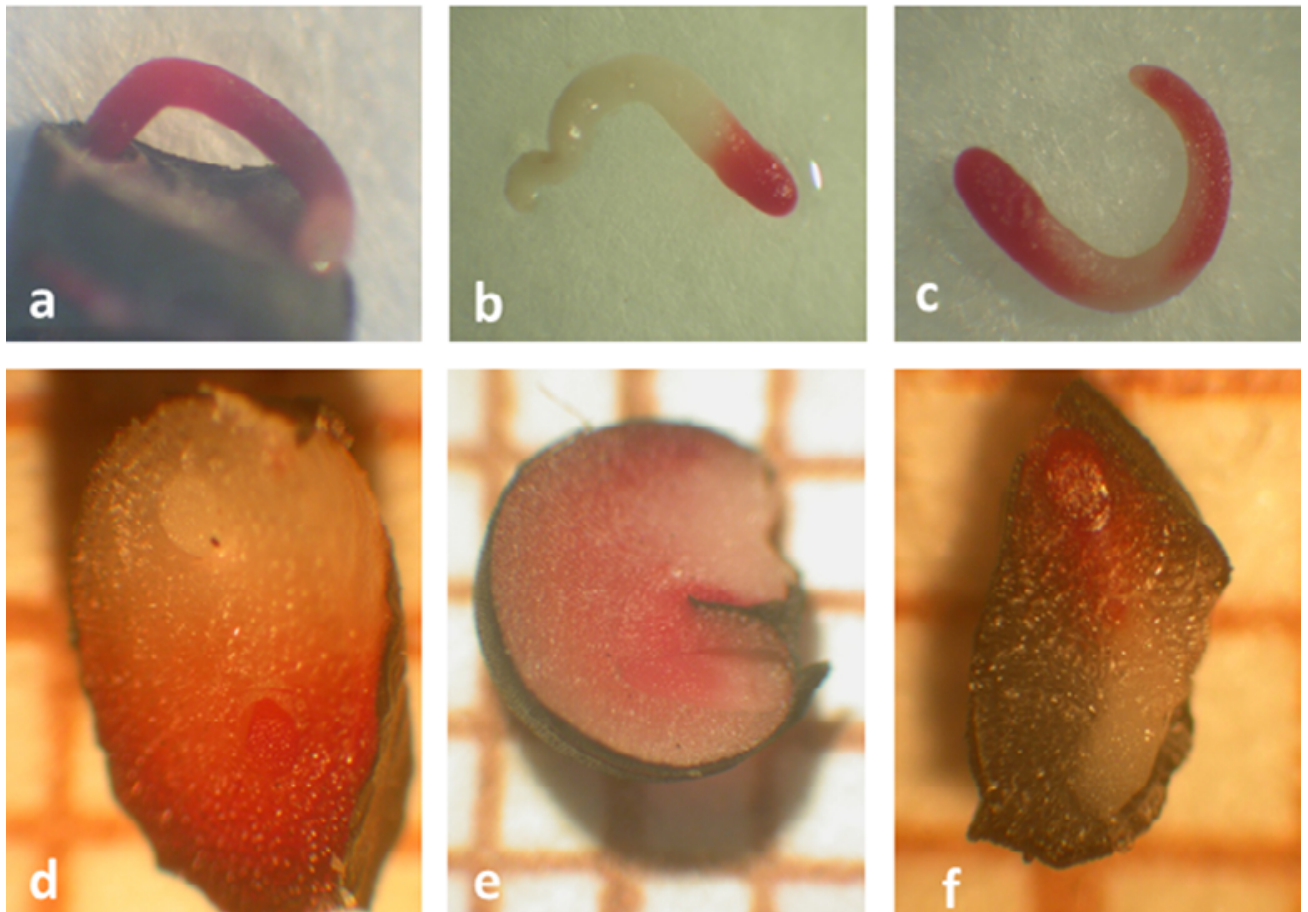

Fig. 4 Tetrazolinum test for seed viability and vigour carried out on day 21 of the experiment. a,d Allium victorialis. b,e A. tuberosum. c,f $A$. angulosum. 
Tab. 2 Strength and energy germination of tested Allium species.

\begin{tabular}{|c|c|c|c|c|c|c|}
\hline \multirow[b]{2}{*}{ Allium species } & \multicolumn{4}{|c|}{ Number of germinated seeds $/ 180$ seeds } & \multirow{2}{*}{$\begin{array}{c}\text { The strength of germination } \\
\text { after } 10 \text { days }(\%)\end{array}$} & \multirow{2}{*}{$\begin{array}{c}\text { The energy of germination } \\
\text { after } 21 \text { days (\%) }\end{array}$} \\
\hline & After 7 days & After 10 days & After 14 days & After 21 days & & \\
\hline A. tuberosum & 60 & 98 & 113 & 172 & 54.44 & 95.55 \\
\hline A. angulosum & - & - & 30 & 45 & 0 & 25 \\
\hline A. victorialis & - & - & - & - & 0 & 0 \\
\hline
\end{tabular}

Statistically significant differences $(P<0.05)$ were observed for all terms.

and energetic substances for the developing embryo. Protoplasts with starch grains were gradually consumed by the new developing plant - a young sporophyte (Fig. 2b). The seeds in all the Allium species examined differed in their size, shape, and surface sculpture (Fig. 1c,d, Fig. 2c,d, Fig. 3a). Immediately under the seed coat, there was an aleuronic layer of elongated cells arranged perpendicular to the seed coat (Fig. 3b). Isodiametric cells filled with numerous starch grains were located deeper (Fig. 3c).

After 21 days of the experiment, young developing embryos were observed in the seeds of all the species examined (Fig. 3d). The tetrazolium test revealed viability of the embryos developing inside the seeds (Fig. $4 \mathrm{a}-\mathrm{c}$ ).

\section{Estimation of the strength and energy of germination}

The experimental results presented in Tab. 2 reveal that the seed germination energy estimated after 10 days was the same (0\%) in A. angulosum and A. victorialis, while in A. tuberosum it reached $54.16 \%$. Moreover, A. tuberosum was characterized by high germination strength reaching 95.83\%. After 21 days, A. victorialis seeds remained dormant. Statistically significant differences $(P<0.05)$ were observed for all terms.

In order to facilitate germination of the A. victorialis embryo, the seeds were incised with a scalpel to ensure better access of water and gases. Additionally, the seeds were stratified at $4^{\circ} \mathrm{C}$ for 7 days. Neither of the treatment applied activated development of the embryo, although it was proved viable by the tetrazolium test (Fig. $4 \mathrm{~d}-\mathrm{f}$ ).

\section{Phylogenetic analyses}

After examination of germination strength and energy, an analysis was performed to assess the genetic similarity of $A$. victorialis to the other Allium species.

Amplification of the plant genetic material yielded amplicons of 700-bp length (Fig. 5). The phylogenetic analysis of nucleotide sequences in the DNA amplification products from A. victorialis, A.uberosum and A. angulosum revealed the highest similarity of the IST region between $A$. victorialis and $A$. tuberosum (Fig. 6). Despite the high homology of the primary structure of the genome fragment, the plants differ substantially in the germination strength. Allium tuberosum seeds were characterized by considerable germination strength and energy, whereas A. victorialis seeds did not exhibit any.

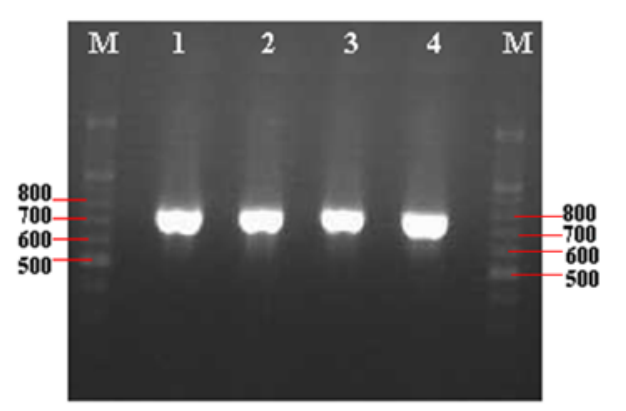

Fig. 5 Electrophoresis of PCR products amplified from leaves with ITS4 and ITS5 in agarose gel stained with ethidium bromide. Lanes: M - M-weight marker; 1 - Allium angulosum; 2 - A. tuberosum; 3 - A. victorialis.

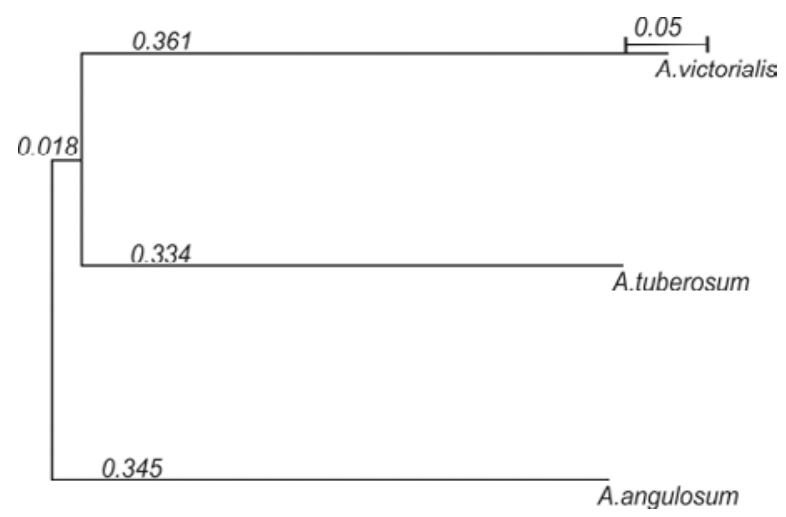

Fig. 6 Comparative phylogenetic analysis of the obtained ITS nucleotide sequences.

\section{Changes in the number of microorganisms and some soil parameters} in root-free-soil, rhizosphere soil and Allium victorialis roots

In order to find possible causes of lack of germination in the case of $A$. victorialis seeds, analysis of soil sampled from natural plant habitats was performed. The high number of fungi (4.5 $\log _{10} \mathrm{CFU}$ of fungi $\times \mathrm{g}^{-1}$ dry mass of soil) and 

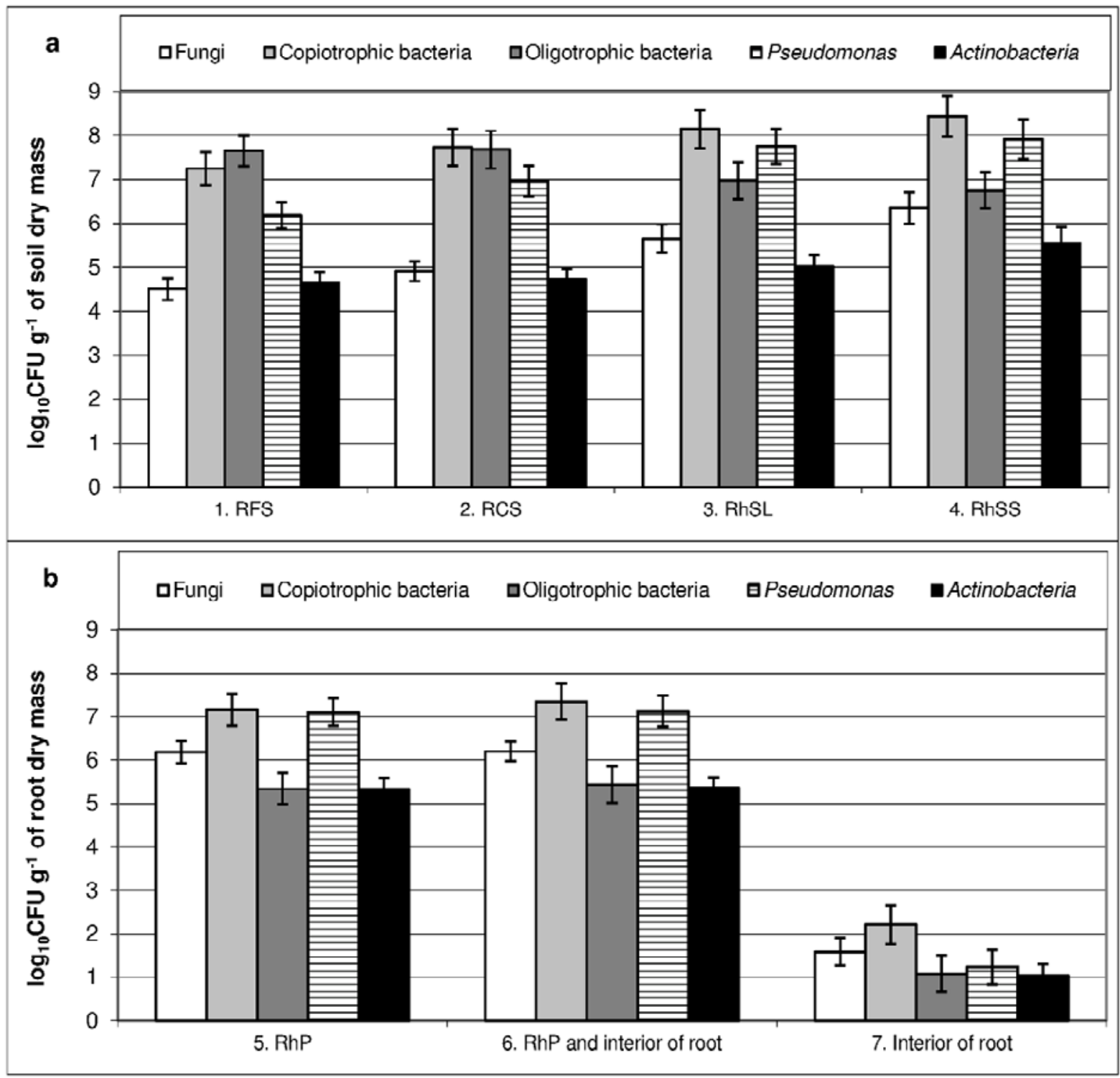

Fig. 7 Number of particular microorganisms in root- free-soil and garlic rhizosphere soil (a), and in garlic rhizoplane and root (b). RFS - root-free soil; RCS - root contaminant soil; RhSL - rhizosphere soil loosely attached to roots; RhSS - rhizosphere soil strongly attached to roots; RhP - rhizoplane.

various groups of bacteria (about $7.0 \log _{10} \mathrm{CFU}$ of bacteria $\times \mathrm{g}^{-1}$ dry mass of soil) were detected in the RFS around garlic roots (Fig. 7a). The number of CFU of the all tested groups of microorganisms increased in the RCS; however, the increase in the number of oligotrophic bacteria was not statistically significant. Only the number of CFU of oligotrophic bacteria decreased in the rhizosphere soil (Fig. 7b). The number of CFU of the other tested groups of microorganisms increased distinctly (about 10 fold) in the rhizosphere soil. The garlic rhizoplane was also inhabited by all the tested groups of microorganisms: especially by copiotrophic bacteria and bacteria from the genus Pseudomonas. The rhizoplane of garlic was colonized by above $6.0 \log _{10} \mathrm{CFU}$ of fungi $\times \mathrm{g}^{-1}$ dry mass of roots. In the interior of $A$. victorialis roots, the number of microorganisms decreased 1000 to 10000 times but all the tested microbial groups, especially copiotrophic bacteria and fungi (1.6 and 2.2, respectively, $\log _{10} \mathrm{CFU} \times \mathrm{g}^{-1}$ dry mass of roots) were detected.

Changes in such parameters as dehydrogenase activity, $\mathrm{pH}$ values, and the TOC content in the particular parts of the rhizosphere and in comparison to the rhizosphere with root-free-soil were observed (Fig. 8). A gradual increase in dehydrogenase activity (Fig. 2a) and the TOC content (Fig. 8) from RFS to RhSS was detected as well as a gradual decrease in the $\mathrm{pH}$ values (Fig. $8 \mathrm{~b}$ ). The dehydrogenase activity and TOC content were highly positively correlated with the total number of CFU of the microorganisms ( $r=$ 0.918 and 0.93 , respectively). 

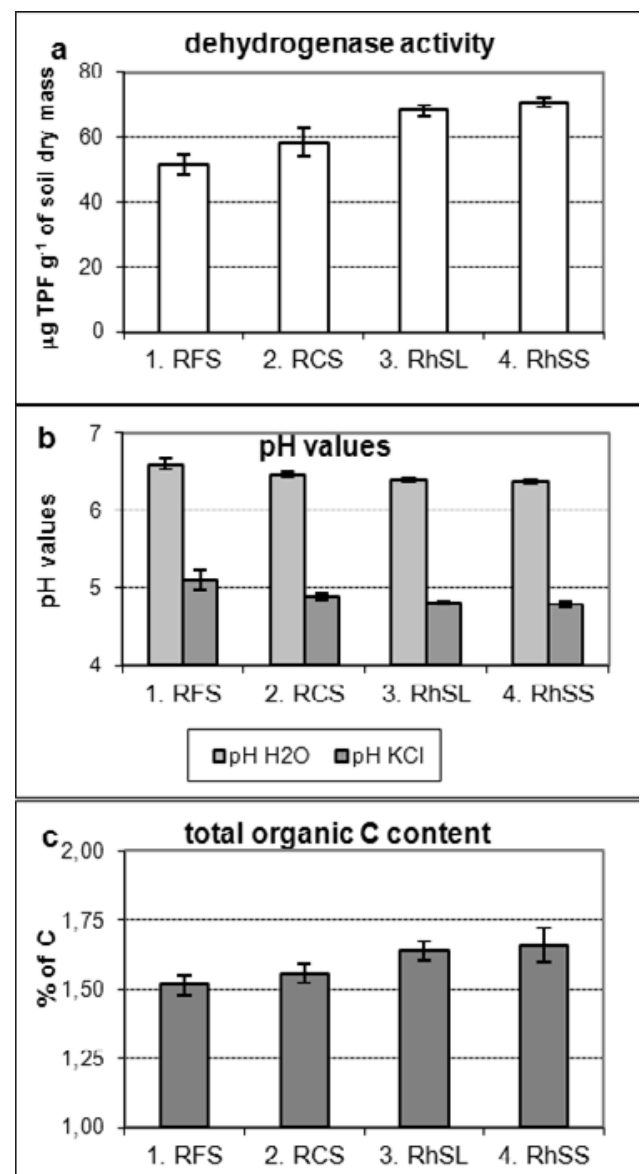

Fig. 8 Dehydrogenase activity (a), $\mathrm{pH}$ values $(\mathbf{b})$ and total organic $\mathrm{C}$ content $(\mathbf{c})$ in root-free-soil and garlic rhizosphere soil. RFS root-free soil; RCS - root contaminant soil; RhSL - rhizosphere soil loosely attached to roots; RhSS - rhizosphere soil strongly attached to roots; $\mathrm{RhP}$ - rhizoplane.

\section{Discussion}

In European conditions, A. victorialis (victory onion, alpine leek) can be found in few, isolated localities or is introduced in botanical gardens. This implies a considerable impact of climatic conditions, geographical location, and the environment on the strength and energy of seed germination in the victory onion. The results of our scanning microscopy examinations have excluded anatomical and morphological abnormalities in the seed structure that could inhibit the germination process. All seed structures such as the embryo and endosperm developed normally, in a manner characteristic for all species from the Allium genus. Moreover, the tetrazolium test revealed viability of the embryos in the examined seeds. The present study consisted in tests of germination strength and energy in the laboratory under recommended optimal conditions for Allium germination outlined by the International Seed Testing Association [14]. Although all the recommendations were implemented, no germination was observed in A. victorialis. Additional scarification and stratification treatments did not improve the dynamics of A. victorialis seed germination. The germination strength and energy did not change and remained at a zero level, which may imply that the treatments cannot improve the generative reproduction of this species. Scarification of onion (A. cepa) seeds not only reduced germination parameters but also contributed to fungal infections [22].

Some authors emphasize the impact of bacteria, actinomycetes, and fungi on the rhizosphere and plant root tissue $[23,24]$. The above-mentioned microorganisms detoxify secondary metabolites, which in turn may inhibit seed germination in in vitro conditions $[25,26]$. Since young individuals developing from seeds can be found in nature, it was hypothesized that the germination process is correlated with soil microflora.

The studies on intensity of colonization of $A$. victorialis rhizosphere soil and garlic roots by particular microbial groups and dehydrogenase activity indicated that the rhizosphere effect is present in the garlic rhizosphere just as in many other plants $[27,28]$. The rhizosphere effect is often evaluated in terms of the $R / S$ ratio, where $R=$ the number of microbes in the rhizosphere and $S=$ the number of similar microbes in bulk soil. Equally typical for plant rhizosphere, the number of fungal CFU was generally lower than the number of bacterial CFU. Literature data about microorganisms inhabiting the garlic rhizosphere and root is sparse. Garlic diseases such as basal rot disease in garlic infected by Fusarium oxysporum fungi [29] and white-rot disease in garlic infected by Sclerotium cepivorum fungi [30] are frequently described. There are also publications describing beneficial fungi (e.g. Trichoderma harzianum) and bacteria colonizing the root region of garlic plants and effective in biocontrol of fungal phytopathogens. Research papers provide information about arbuscular mycorrhizal fungi $[31,32]$ rather than about other endophytic fungi colonizing garlic roots [33].

The present study and literature data do not allow identification of the causes of inhibited $A$. victorialis germination. Despite the high genetic homology between $A$. victorialis and A. tuberosum, the species differ markedly in their ability of seed germination. This may imply the effect of yet unknown gene mutations or varied expression of the same regions with the same genetic structure. Investigations into the physiology of seed germination have shown that some seeds will not germinate even in favorable habitat conditions, as they display absolute dormancy caused by, e.g. immaturity of the embryo or accumulation of inhibitors of growth and development [5]. An important stage in the germination process is initiation of the imbibition phase, which is only possible in conditions of high humidity and suitable temperature. These conditions were fulfilled in the present study but the seeds did not germinate; therefore, it can be concluded that other factors should be employed in overcoming seed dormancy. It seems advisable that the levels of abscisic acid and other germination inhibitors, e.g. phenols and their derivatives, should be determined, as their high concentrations may substantially inhibit $A$. victorialis germination. The similarity of 13 species and five ornamental cultivars of Allium was studied by Kamenetsky and Rabinowitch [34].

In order to determine unequivocally the causes of seed germination inhibition and low energy and strength, further investigations are indispensable focused on photoperiodic and temperature changes and biochemical analyses 
(especially of such growth regulators as auxins, gibberellins and abscisic acid). Solving the problem of inhibited

\section{Acknowledgments}

This study was supported by the basic funds for maintaining research potential at the Faculty of Biology and Biotechnology of UMCS in Lublin. The authors would like to acknowledge two anonymous reviewers for constructive and helpful comments.

\section{Authors' contributions}

The following declarations about authors' contributions to the research have been made: hypothesis of the study, writing of the manuscript: KW; microscopical analysis: KW, KS; photographs: KW, KS; microbial analysis of root-free soil, rhizosphere soil and roots, dehydrogenase activity: JJŚ; data analysis: JB.

\section{References}

1. Moïse JA, Han S, Gudynaitę-Savitch L, Johnson DA, Miki BLA. Seed coats: structure, development, composition, and biotechnology. Vitro Cell Dev Biol Plant. 2005;41(5):620-644. http://dx.doi.org/10.1079/ IVP2005686

2. Mallek SB, Prather TS, Stapleton JJ. Interaction effects of Allium spp. residues, concentrations and soil temperature on seed germination of four weedy plant species. Appl Soil Ecol. 2007;37(3):233-239. http:// dx.doi.org/10.1016/j.apsoil.2007.07.003

3. Beligni MV, Lamattina L. Nitric oxide stimulates seed germination and de-etiolation, and inhibits hypocotyl elongation, three lightinducible responses in plants. Planta. 2000;210(2):215-221. http:// dx.doi.org/10.1007/PL00008128

4. Mathew SJ, Rembold M, Leptin M. Role for Traf4 in polarizing adherens junctions as a prerequisite for efficient cell shape changes. Mol Cell Biol. 2011;31(24):4978-4993. http://dx.doi.org/10.1128/ MCB.05542-11

5. Bewley JD. Seed germination and dormancy. Plant Cell. 1997;9(7):1055-1066. http://dx.doi.org/10.1105/tpc.9.7.1055

6. Fritsch RM, Friesen N. Evolution, domestication, and taxonomy. In: Rabinowitch HD, Currah L, editors. Allium crop science: recent advances. Wallingford: CABI; 2002. p. 5-26.

7. Hanelt P. Alliaceae. In: Hanelt P, Büttner R, Mansfeld R, editors. Mansfeld's encyclopedia of agricultural and horticultural crops (except ornamentals). Vienna: Springer; 2001. p. 2250-2269.

8. Mirek Z, Piękoś-Mirkowa H, Zając A, Zając M, editors. Flowering plants and pteridophytes of Poland - a checklist. Cracow: W. Szafer Institute of Botany, Polish Academy of Sciences; 2002. (Biodiversity of Poland; vol 1).

9. Bilz M, Kell SP, Maxted N, Lansdown RV. European red list of vascular plants. Luxembourg: Publications Office of the European Union; 2011. http://dx.doi.org/10.2779/8515

10. Kawano S, Nagai Y. Life-history monographs of Japanese plants. 4: Allium victorialis L. ssp. platyphyllum (Makino) Hulten (Alliaceae) Syn. Allium victorialis L. var. platyphyllum Makino; A. latissimum Prokh. Plant Species Biol. 2005;20(3):219-225. http://dx.doi. org/10.1111/j.1442-1984.2005.00141.x

11. Rätsch C. The encyclopedia of psychoactive plants: ethnopharmacology and its applications. Rochester, NY: Inner Traditions/Bear; 2012.

12. Alef K. Dehydrogenase activity. In: Alef K, Nannipieri P, editors. Methods in applied soil microbiology and biochemistry. London: Academic Press; 1995. p. 228-231.

13. Hirschegger P, Jakse J, Trontelj P, Bohanec B. Origins of Allium ampeloprasum horticultural groups and a molecular phylogeny of the section Allium (Allium: Alliaceae). Mol Phylogenet Evol. 2010;54(2):488-497. http://dx.doi.org/10.1016/j.ympev.2009.08.030

14. International Seed Testing Association. International rules for seed testing. Bassersdorf: International Seed Testing Association; 2010.

15. Graber ER, Harel YM, Kolton M, Cytryn E, Silber A, David DR, et al. Biochar impact on development and productivity of pepper and tomato
A. victorialis germination will be of great importance for conservation of this valuable, endangered species.

grown in fertigated soilless media. Plant Soil. 2010;337(1-2):481-496. http://dx.doi.org/10.1007/s11104-010-0544-6

16. Lityński T, Jurkowska H, Gorlach E. Analiza chemiczno-rolnicza: przewodnik metodyczny do analizy gleby i nawozów. Warsaw: Polish Scientific Publishers PWN; 1976.

17. King EO, Ward MK, Raney DE. Two simple media for the demonstration of pyocyanin and fluorescin. J Lab Clin Med. 1954;44(2):301-307.

18. Martin JP. Use of acid, rose bengal, and streptomycin in the plate method for estimating soil fungi. Soil Sci. 1950;69(3):215-232. http:// dx.doi.org/10.1097/00010694-195003000-00006

19. Tabatabai MA. Soil enzymes. In: Page AL, Keeney DR, editors. Methods of soil analysis. Part 2. Chemical and microbiological properties. Madison, WI: American Society of Agronomy, Soil Science Society of America; 1982. p. 903-948.

20. Thalmann A. Zur Methodik der Bestimmung der Dehydrogenaseaktivität im Boden mittels Triphenyltetrazoliumchlorid (TTC). Landwirtsch Forsch. 1968;21:249-258.

21. Armitage P, Berry G, Matthews JNS. Statistical methods in medical research. Oxford: Blackwell; 1987.

22. Sardi P, Saracchi M, Quaroni S, Petrolini B, Borgonovi GE, Merli S. Isolation of endophytic Streptomyces strains from surface-sterilized roots. Appl Env Microbiol. 1992;58(8):2691-2693.

23. Azaizeh HA, Marschner H, Römheld V, Wittenmayer L. Effects of a vesicular-arbuscular mycorrhizal fungus and other soil microorganisms on growth, mineral nutrient acquisition and root exudation of soil-grown maize plants. Mycorrhiza. 1995;5(5):321-327. http://dx.doi. org/10.1007/BF00207404

24. Schroth MN, Hildebrand DC, Starr MP. Phytopathogenic members of the genus Pseudomonas. In: Starr MP, Stolp H, Trüper HG, Balows A, Schlegel HG, editors. The Prokaryotes. Berlin: Springer Berlin Heidelberg; 1981. p. 701-718.

25. Leifert C, Murphy K, Lumsden P. Mineral and carbohydrate nutrition of plant cell and tissue cultures. Crit Rev Plant Sci. 1995;14(2):83-109. http://dx.doi.org/10.1080/07352689509701923

26. Kuzyakov Y. Review: factors affecting rhizosphere priming effects. J Plant Nutr Soil Sci. 2002;165(4):382-396. http://dx.doi. org/10.1002/1522-2624(200208)165:4<382::AID-JPLN382>3.0.CO;2-\#

27. Raaijmakers JM, Paulitz TC, Steinberg C, Alabouvette C, MoënneLoccoz Y. The rhizosphere: a playground and battlefield for soilborne pathogens and beneficial microorganisms. Plant Soil. 2009;321(12):341-361. http://dx.doi.org/10.1007/s11104-008-9568-6

28. Fatawi ZD, Wiyono H, Widono S. Analysis of rhizosphere bacterial community in suppressive and conducive soils to basal rot of garlic based on PCR-RISA. Biomirror. 2012;3(2):9-12.

29. Avila Miranda ME, Herrera Estrella A, Peña Cabriales JJ. Colonization of the rhizosphere, rhizoplane and endorhiza of garlic (Allium sativum L.) by strains of Trichoderma harzianum and their capacity to control allium white-rot under field conditions. Soil Biol Biochem. 2006;38(7):1823-1830. http://dx.doi.org/10.1016/j.soilbio.2005.11.036

30. Rajeshkumar S, Nisha MC. Diversity of arbuscular mycorrhizal fungi associated with some garlic varieties in Nilgiri District. Herb Tech Ind. 2012;3:1-3.

31. Thangavelu M, Tamilselvi V. Occurrence and morphology of endorhizal fungi in crop species. Trop Subtrop Agroecosyst. 2010;12(3):593-604.

32. Rodriguez RJ, White JF, Arnold AE, Redman RS. Fungal endophytes: diversity and functional roles. New Phytol. 2009;182(2):314-330. http://dx.doi.org/10.1111/j.1469-8137.2009.02773.x

33. Krzymińska A, Gawłowska M, Wolko B, Bocianowski J. Genetic diversity of ornamental Allium species and cultivars assessed with isozymes. J Appl Genet. 2008;49(3):213-220. http://dx.doi.org/10.1007/ BF03195616

34. Kamenetsky R, Rabinowitch HD. Floral development in bolting garlic. Sex Plant Reprod. 2001;13(4):235-241. http://dx.doi.org/10.1007/ s004970000061 